ISSN:2656-4270 (Online) 1410-4466 (Print) Accredited by Ministry of Research, Technology, and Higher Education with the ranking of Sinta (S4) SK NO.28/E/KPT/2019, 26th September 2019
Buletin Penelitian Sosial Ekonomi Pertanian Fakultas Pertanian Universitas Haluoleo

2020:22(2):72-81

http://ojs.uho.ac.id/index.php/sosek

doi: http://dx.doi.org/10.37149/sosek.v22i2.14242

\title{
FARMING ANALYSIS AND MARKETING STRATEGY OF RED GUAVA (Psidium guajava L.) IN KARANGANYAR DISTRICT
}

\author{
Jihan Khairrunnisa $^{\left.{ }^{*}\right)}$, Endang Siti Rahayu ${ }^{1)}$, Agustono ${ }^{1)}$ \\ ${ }^{1}$ Universitas Sebelas Maret \\ ${ }^{*}$ Corresponding author: jihankhairrunnisa98@gmail.com
}

To cite this article:

Khairrunnisa, J., Rahayu, E., \& Agustono, A. (2020). Farm Analysis and Marketing Strategy of Red Guava (Psidium guajava L.) in Karanganyar District. Buletin Penelitian Sosial Ekonomi Pertanian Fakultas Pertanian Universitas Haluoleo, 22(2), 72 - 81. doi:http://dx.doi.org/10.37149/bpsosek.v22i2.14242

Received: September 22, 2020; Accepted: January 25, 2020; Published: January 28, 2020

\begin{abstract}
This study aimed to determine the feasibility of farming and identify internal and external factors in the marketing of red guava in Karanganyar District. The basic methods of this research are descriptive and analytical methods. The research location was chosen purposively in Karanganyar District, while the sampling of red guava farmers was done by using Snowball Sampling technique. The data analysis methods used are (1) Farming feasibility analysis by calculating NPV, IRR, Net B/C Ratio, and payback period, while (2) Marketing strategy was analyzed using IFE, EFE, Grand Strategy, and SWOT analysis. The results showed that the total cost of producing red guava was IDR $390,525,560$ per hectare with benefits obtained by farmers was IDR665,129,380 per hectare. The calculation results of the feasibility of red guava farming on NPV, IRR, Net B/C Ratio, and payback period were respectively IDR $66,717,379.00$ per $\mathrm{Ha}, 22.88 \%, 1.50$, and 6 years, indicating that red guava farming in Karanganyar District is worthy. Based on the results of Grand Strategy matrix analysis, it is known that the difference between the strength and weakness factors was 1.427 and the opportunity factor with the threat was 1.829 , placing red guava in quadrant I. The resulting alternative strategies were in the SO (Strengths-Opportunities) strategy.
\end{abstract}

Keywords: farming feasibility; grand strategy; marketing; red guava; SWOT.

\section{INTRODUCTION}

Agriculture is a sector that has a very important role in economic development in Indonesia (Fortunika, 2017). The agricultural sub-sector easy to develop is horticulture. Horticulture has great potential to be developed because it has an influence on improving the nutrition, income, and welfare of farmers. Horticulture is used to meet daily food needs so that the harvest is always needed by many people in general (Aluhariandu, 2016).

One of the horticultural products developed in Indonesia is red guava. Red guava (Psidium guajava L.) is one of fruits favored by community because of its delicious taste and aroma, high vitamin C content, and many other health benefits (Susanto, 2018). Red guava is widely known in various circles of society, both those who live in urban and rural areas. People can consume this fruit in the fresh form (as table fruit) and used it as raw material for processed food such as syrup, fruit juice, jam, and jelly. In addition, Indonesia's fertile natural conditions can support its growth.

Based on Indonesia Statistics (BPS) data in 2019, Central Java is the highest producer of red guava in Indonesia. Central Java contributed $27.62 \%$ of the production. The production of this red guava is in every District/City in Central Java. One of the areas in Central Java that produce red guava is Karanganyar District.

Karanganyar District occupies the $11^{\text {th }}$ position with a total production of 19,435 quintals. From these results, it can be seen that the production of red guava in Karanganyar District is still low compared to other regions. This is because red guava has not been developed much in Karanganyar District. However, the production of red guava in Karanganyar District is able to supply the needs of red guava market in other areas, such as Sragen, Solo, Ngawi, and other areas. 
The production of red guava in Karanganyar District always increased every year. It can be seen that red guava farming is growing. The factor that affects the potential to develop red guava farming is continuous demand. Based on Indonesia Statistics of Karanganyar in 2019, sub-districts that have high production in Karanganyar District are Ngargoyoso, Tawangmangu, and Jenawi Districts which contribute to the production of red guava in Karanganyar District by $72.31 \%, 6.24 \%$, and $5.95 \%$, respectively.

Karanganyar District has potential in developing farming which is used to increase community income. People in Karanganyar District continuously try to carry out marketing activities of red guava in the hope that this business can meet their daily needs. The community realizes that even though they do not have good management and high basic education, they continue to work on it. Although this business seems to run smoothly, it does not mean that it does not have a problem. Farmers in marketing red guava only rely on traders/middlemen in each village so this results in different prices between farmers. The absence of one-stop marketing makes red guava products have a low price. In addition, the large supply of red guava in various regions offered to consumers is a threat to their acceptable products. Therefore, it is necessary to formulate a marketing strategy in order to help farmers in Karanganyar District face various problems and risks. The marketing of red guava is influenced by various factors. These factors can be in the form of internal factors or external factors. These internal and external factors will be very important in order to create an appropriate and effective marketing strategy to improve the cultivation of red guava in Karanganyar District in the future.

The farm analysis activity also has an important role in the cultivation of red guava. Farmers in conducting cultivation generally do not have farming records, so it is difficult for farmers to carry out their farming analysis. The existence of farming analysis will later assist farmers in obtaining information on managing their farming in order to create increased productivity so that their profits can increase.

Karanganyar District has the potential to cultivate red guava, so its management needs to be improved to provide maximum benefits. Therefore, it is necessary to conduct research to determine whether red guava in Karanganyar District is feasible to be developed by farmers and what strategies are appropriate to be implemented. The purpose of this study was to determine the feasibility of farming and identify internal and external factors in the marketing of red guava in Karanganyar District where the right marketing strategy was identified.

\section{MATERIALS AND METHODS}

The location of the sample was determined purposively (intentionally), which is in Karanganyar District because it is one of the producers of red guava in Central Java and has the potential to be developed. The respondents involved was divided into two parts, which are for farming analysis and marketing strategies. The determination of the number of farming respondents was carried out by proportional sampling with 40 farmers chosen as respondents. The determination of the sample of red guava farmers in this study used snowball sampling technique. Snowball sampling is a sample determination technique in which at first, it has small amount but then gets bigger (Sugiyono, 2011). The determination of marketing strategy sample was based on certain informants or situations who can provide information in accordance with the research focus. This study used primary and secondary data. The data collection technique was done through observation, interview, and documentation. The analysis methods include:

1. Farming Analysis (Pasaribu, 2012)

a. Net Present Value (NPV)

Mathematically it can be formulated as follows:

Information :

$$
\mathrm{NPV}=\sum_{t=1}^{n} \frac{\mathrm{Bt}-\mathrm{Ct}}{(1+\mathrm{i})^{\mathrm{n}}}
$$

$\mathrm{Bt}$ is the flow of revenue (benefit) from year 1 to year $\mathrm{n}$ (end of project life), $\mathrm{Ct}$ is the flow of expenses (cost) from year 1 to the end of the project life, and I am the discount rate.

The assessment criteria are as follows:

NPV $>0$ : Cultivation of red guava is feasible / profitable

$N P V<0$ : Red guava farming is not feasible to be cultivated/loses

$N P V=0$ : Red guava farming is at the break-even point 
b. Internal Rate of Return (IRR)

Mathematically it can be formulated as follows:

Information :

$$
\operatorname{IRR}=i_{o}+\left(\mathrm{i}_{1}-\mathrm{i}_{0}\right) \frac{\mathrm{NPV}_{0}}{\left(\mathrm{NPV}_{0}-\mathrm{NPV}_{1}\right)}
$$

$\boldsymbol{i}_{\boldsymbol{o}}$ is the prevailing interest rate (opportunity cost of capital),

$\boldsymbol{i}_{1}$ is the comparative interest rate (comparator discount rate),

The assessment criteria are as follows:

$\mathrm{NPV}_{0}$ is NPV at $i_{o}$, and NPV is NPV at $i_{1}$.

IRR $>r \quad$ : Farming red guava is feasible/profitable

IRR<r : Red guava farming is not feasible to be cultivated/loses

IRR=r : Red guava farming is at the break-even point

c. Net B / C Ratio

Mathematically it can be formulated as follows:

The assessment criteria are as follows:

$$
\text { Net B/C }=\frac{\sum_{\mathrm{t}=0}^{\mathrm{n}} \text { NPV Positif }}{\sum_{\mathrm{t}=0}^{\mathrm{n}} \text { NPV Negatif }}
$$

Net $B / C>1$ : Red guava farming is feasible to cultivate / profit

Net $B / C<0$ : The red guava farming is not feasible to cultivate/lose

Net $B / C=0$ : Red guava farming is at the break-even point

d. Payback Period

Mathematically it can be formulated as follows:

Payback Period $=$ Investment / (Net Cash / year) $\mathrm{x} 1$ year

$$
\text { Payback Period }=\frac{\text { Investation }}{\text { Net Cash } / \text { Year }} \times 1 \text { Year }
$$

The assessment criteria are as follows:

- The greater the Payback Period value, the longer the return on investment invested in red guava farming

- The smaller the Payback Period value, the faster the return on investment invested in red guava farming

\section{Marketing Strategy (David, 2009)}

The analytical method used includes analysis of internal and external factors, analysis of farming position, and analysis of alternative strategies. The identification of internal factors aimed to identify factors which become strengths and weaknesses in marketing including the product, price, distribution, promotion, finance, and management. The identification of external factors aimed to identify factors that become opportunities and threats in marketing which include marketers, consumers, government, environmental, and socio-cultural intermediaries, as well as competitors. The farming position analysis was used to determine the position of red guava farm in Karanganyar District based on Grand Strategy matrix. Grand Strategy matrix is included in the matrix used in the matching stage where the matrix was based on information from the input stage to match external opportunities and threats with internal strengths and weaknesses. An alternative marketing strategy for red guava used SWOT matrix analysis. The SWOT matrix can clearly describe how opportunities and threats from external factors faced by a business can be adjusted according to its strengths and weaknesses.

\section{RESULTS AND DISCUSSION}

\section{Respondent Characteristics}

The respondent of red guava farming in Karanganyar District has an average age of 49 years old. People who are at productive age have a high enthusiasm for developing their business because they are driven by high needs and are able to do this farming (Theresia, 2016). The level of education will affect the readiness of farmers to accept and absorb new technology and information. Education will be a factor affecting farmers' attitudes in making decisions (Muta'ali, 2019). On average, respondents had a low level of education that is, graduated from elementary school. The average farmer has been cultivating this red guava for 6 years. Farmers who have longer experience cultivating guava will understand the farming situation, conditions, and constraints so that it will be easier to manage and minimize the risk of failure. The number of farmer family members was 4 people. Each family has 2 members who were active in cultivating red guava. The limited number of family members who play an active role in red guava farming activities causes farmers to use outside labor. 


\section{Analysis of Red Guava Farming}

In farming, plants can be grouped into two groups, namely annual plants and seasonal plants. Perennial plants are plants that require a long time to produce. The period of annual crop production usually reaches tens of years and can be harvested more than once (Kapantaw, 2017). Red guava is an annual plant that bears fruit throughout the year and can be harvested more than once.

The cost of producing red guava farming is divided into initial investment costs and operational costs. Investment costs are the costs incurred at the beginning of the business before the plant produces a plant with the hope that it can benefit in the next few years. Investment costs are spent to meet the facilities and infrastructure needed to develop the business. The land area used was $1 \mathrm{Ha}$.

Table 1. Analysis of initial investment cost of red guava farming

\begin{tabular}{|c|c|c|c|c|}
\hline No & Description & $\begin{array}{c}\text { Total } \\
\text { Requirements }\end{array}$ & $\begin{array}{l}\text { Unit Price } \\
\text { (IDR) }\end{array}$ & $\begin{array}{l}\text { Total } \\
\text { (IDR) }\end{array}$ \\
\hline & & Fixed cost & & \\
\hline \multirow{10}{*}{$\begin{array}{l}1 . \\
2 .\end{array}$} & Land lease & 1 & 84.000 .000 & 84.000 .000 \\
\hline & Farming Equipment & & & \\
\hline & Hoe & 8 & 70.000 & 560.000 \\
\hline & Sickle & 5 & 50.000 & 250.000 \\
\hline & Spray Tool & 3 & 350.000 & 1.050 .000 \\
\hline & Scissor & 12 & 60.000 & 720.000 \\
\hline & Diesel & 1 & 3.500 .000 & 3.500 .000 \\
\hline & Rickshaw & 2 & 500.000 & 1.000 .000 \\
\hline & Total Equipment & & & 7.080 .000 \\
\hline & Total Fixed Costs & & & 91.080 .000 \\
\hline & & Variable Costs & & \\
\hline 1. & Seeds & 400 & 20.750 & 8.300 .000 \\
\hline 2. & Manure & 185 & 5.000 & 925.000 \\
\hline \multirow[t]{5}{*}{3.} & Chemical Fertilizers & & & \\
\hline & Phonska fertilizer & 4,51 & 5.000 & 22.550 \\
\hline & ZA fertilizer & 4,51 & 5.000 & 22.550 \\
\hline & NPK Fertilizer & 0,73 & 12.000 & 8.760 \\
\hline & Total Chemical Fertilizers & & & 93.085 \\
\hline \multirow[t]{7}{*}{4.} & Labor & & & \\
\hline & Land Processing & 8 & 52.250 & 418.000 \\
\hline & Planting & 5 & 52.250 & 261.250 \\
\hline & Fertilization & 5 & 52.250 & 261.250 \\
\hline & Total Workforce & & & 940.500 \\
\hline & \multirow{2}{*}{\multicolumn{2}{|c|}{$\begin{array}{c}\text { Total Variable Costs } \\
\text { Total Initial Investment Cost }\end{array}$}} & & 10.219 .360 \\
\hline & & & & 101.299 .360 \\
\hline
\end{tabular}

Source: Primary Data Analysis, 2020

The average initial investment cost for red guava farming in Karanganyar District was $101,229,360.00 /$ ha. This initial investment cost consists of fixed costs and variable costs. The largest costs incurred were fixed costs of $91,080,000.00 / \mathrm{Ha}$. Fixed costs consist of the cost of renting land and farming equipment. The biggest expense in fixed costs is in the cost of renting land because the land used to cultivate this red guava for 7 years.

Operational costs are the costs incurred while managing the farm or after the plants produce (Kusumawati, 2013). Operational costs consist of fixed costs and variable costs. Fixed costs consist of replacement costs for equipment, while variable costs consist of costs for fertilizers, pesticides, packaging, and labor. Cultivation of red guava was carried out for 7 years with different expenses each year.

Table 2. Analysis of red guava operational costs

\begin{tabular}{llllr}
\hline \multirow{2}{*}{ No } & \multirow{2}{*}{ Description } & \multicolumn{3}{c}{ Cost } \\
\cline { 2 - 5 } & Year 1 & Year 2 & Year 3 & Year 4 \\
\hline Fixed cost & & & & \\
1. Farming Equipment & & & 0 & 0 \\
\multicolumn{1}{l}{ Hoe } & 0 & 0 & 0 & 0 \\
\hline
\end{tabular}


Table 2. Analysis of red guava operational costs

\begin{tabular}{|c|c|c|c|c|c|}
\hline \multirow{2}{*}{ No } & \multirow{2}{*}{ Description } & \multicolumn{4}{|c|}{ Cost } \\
\hline & & Year 1 & Year 2 & Year 3 & Year 4 \\
\hline & Sickle & 0 & 0 & 0 & 0 \\
\hline & Scissor & 0 & 0 & 720.000 & 0 \\
\hline \multicolumn{6}{|c|}{ Variable Costs } \\
\hline 1. & Manure & 925.000 & 925.000 & 3.400 .000 & 3.400 .000 \\
\hline \multirow{5}{*}{2.} & Chemical Fertilizers & & & & \\
\hline & Ponska fertilizers & 562.500 & 1.075 .000 & 1.075 .000 & 1.075 .000 \\
\hline & ZA fertilizer & 500.000 & 975.000 & 975.000 & 975.000 \\
\hline & NPK fertilizers & 8.700 & 96.000 & 96.000 & 96.000 \\
\hline & Total Chemical Fertilizers & 1.071 .200 & 2.146 .000 & 2.146 .000 & 2.146 .000 \\
\hline 3. & Wrapping & 30.600 & 595.200 & 1.401 .600 & 2.169 .600 \\
\hline \multirow[t]{6}{*}{4.} & Pesticide & & & & \\
\hline & Curacron & 756.000 & 756.000 & 756.000 & 756.000 \\
\hline & Regent & 470.400 & 470.400 & 470.400 & 470.400 \\
\hline & Antonik & 218.400 & 218.400 & 218.400 & 218.400 \\
\hline & Starban & 268.800 & 268.800 & 268.800 & 268.800 \\
\hline & Total Pesticides & 1.713 .600 & 1.713 .600 & 1.713 .600 & 1.713 .600 \\
\hline \multirow[t]{14}{*}{4.} & Labor & & & & \\
\hline & In-Labor & & & & \\
\hline & Fertilization & 1.225 .000 & 1.225 .000 & 1.225 .000 & 1.225 .000 \\
\hline & Weeding & 1.925 .000 & 1.925 .000 & 1.925 .000 & 1.925 .000 \\
\hline & Pest Control for Plant Diseases & 770.000 & 770.000 & 770.000 & 770.000 \\
\hline & Harvesting & 4.620 .000 & 4.620 .000 & 4.620 .000 & 4.620 .000 \\
\hline & Total In-Labor & 8.540 .000 & 8.540 .000 & 8.540 .000 & 8.540 .000 \\
\hline & Outside Labor & & & & \\
\hline & Fertilization & 4.900 .000 & 4.900 .000 & 4.900 .000 & 4.900 .000 \\
\hline & Weeding Plants & 3.675 .000 & 3.675 .000 & 3.675 .000 & 3.675 .000 \\
\hline & Pest Control for Plant Diseases & 980.000 & 980.000 & 1.470 .000 & 1.470 .000 \\
\hline & Harvesting & 9.660 .000 & 9.660 .000 & 11.340 .000 & 14.280 .000 \\
\hline & Total Outside Labor & 19.215 .000 & 19.215 .000 & 21.385 .000 & 24.325 .000 \\
\hline & Total Operating Costs & 31.495 .400 & 33.134 .800 & 39.306 .200 & 42.294 .200 \\
\hline
\end{tabular}

Table 2. Analysis of red guava operational costs

\begin{tabular}{|c|c|c|c|c|}
\hline \multirow{2}{*}{ No } & \multirow{2}{*}{ Description } & \multicolumn{3}{|c|}{ Cost } \\
\hline & & Year 5 & Year 6 & Year 7 \\
\hline \multicolumn{5}{|c|}{ Fixed cost } \\
\hline \multirow{4}{*}{1.} & Farming Equipment & & & \\
\hline & Hoe & 560.000 & 0 & 0 \\
\hline & Sickle & 240.000 & 0 & 0 \\
\hline & Scissor & 0 & 720.000 & 0 \\
\hline \multicolumn{5}{|c|}{ Variable Costs } \\
\hline 1. & Manure & 3.400 .000 & 3.400 .000 & 3.400 .000 \\
\hline \multirow[t]{5}{*}{2.} & Chemical Fertilizers & & & \\
\hline & Ponska fertilizers & 1.075 .000 & 1.075 .000 & 1.075 .000 \\
\hline & ZA fertilizer & 975.000 & 975.000 & 975.000 \\
\hline & NPK fertilizers & 96.000 & 96.000 & 96.000 \\
\hline & Total Chemical Fertilizers & 2.146 .000 & 2.146 .000 & 2.146 .000 \\
\hline 3. & Wrapping & 2.937 .600 & 3.705 .600 & 4.473 .600 \\
\hline \multirow[t]{6}{*}{4.} & Pesticide & & & \\
\hline & Curacron & 756.000 & 756.000 & 756.000 \\
\hline & Regent & 470.400 & 470.400 & 470.400 \\
\hline & Antonik & 218.400 & 218.400 & 218.400 \\
\hline & Starban & 268.800 & 268.800 & 268.800 \\
\hline & Total Pesticides & 1.713 .600 & 1.713 .600 & 1.713 .600 \\
\hline \multirow[t]{3}{*}{4.} & Labor & & & \\
\hline & $\begin{array}{l}\text { In-Labor } \\
\text { Fertilization }\end{array}$ & & 1317500 & \\
\hline & Fertilization & 1.225 .000 & 1.347 .500 & 1.347 .500 \\
\hline
\end{tabular}


Table 2. Analysis of red guava operational costs

\begin{tabular}{llrrr}
\hline \multirow{2}{*}{ No Description } & \multicolumn{3}{c}{ Cost } \\
\cline { 2 - 4 } & & \multicolumn{1}{c}{ Year 5 } & \multicolumn{1}{c}{ Year 6 } & \multicolumn{1}{c}{ Year 7 } \\
\hline Weeding & 1.925 .000 & 2.310 .000 & 2.310 .000 \\
Pest Control for Plant Diseases & 770.000 & 770.000 & 770.000 \\
Harvesting & 4.620 .000 & 4.620 .000 & 4.620 .000 \\
Total In-Labor & 8.540 .000 & 9.047 .500 & 9.047 .500 \\
Outside Labor & & & \\
Fertilization & 4.900 .000 & 5.390 .000 & 5.390 .000 \\
Weeding Plants & 3.675 .000 & 4.410 .000 & 4.410 .000 \\
Pest Control for Plant Diseases & 1.960 .000 & 1.960 .000 & 1.960 .000 \\
Harvesting & 15.960 .000 & 15.960 .000 & 15.960 .000 \\
Total Outside Labor & 26.495 .000 & 27.720 .000 & 27.720 .000 \\
\multicolumn{2}{r}{ Total Operating Costs } & 46.042 .200 & 48.452 .700 & 48.500 .700 \\
\hline
\end{tabular}

Source: Primary Data Analysis, 2020

Most of the costs incurred are for labor costs. This labor cost consists of internal labor and external labor. The workforce in the family is included in the calculation because the workforce in the family still contributes and spends energy in managing the business. In this case, the calculation of the wages for internal workers is the same as for external workers.

Financial feasibility analysis is an analysis of the eligibility criteria seen from the point of view of a business actor. The existence of this business feasibility aims to determine whether the business is financially feasible or not for the invested capital and whether or not it can contribute part of the income for the future. Project evaluation (Evapro) was carried out to determine the benchmarks of a project. The analysis used was NPV (Net Present Value), IRR (Internal Rate of Return), Net B/C Ratio, and payback period.

\begin{tabular}{|c|c|c|c|c|c|c|}
\hline \multirow[b]{2}{*}{$\mathrm{T}$} & \multirow[b]{2}{*}{$\begin{array}{l}\text { Outflow } \\
\text { (Initial and } \\
\text { Operating } \\
\text { Investment } \\
\text { Costs) }\end{array}$} & \multirow[b]{2}{*}{$\begin{array}{l}\text { Inflow } \\
\text { (Benefit) }\end{array}$} & \multirow{2}{*}{$\begin{array}{c}\text { Discount Factor (i) } \\
\begin{array}{c}\mathrm{i}=0,137 \\
\frac{1}{1 /(1+i)^{t}}\end{array}\end{array}$} & \multicolumn{2}{|c|}{ Present Value } & \multirow{2}{*}{$\begin{array}{c}\text { NPV } \\
\text { Net Benefit Flow } \\
\text { time to } t\end{array}$} \\
\hline & & & & $\begin{array}{l}\text { PV Cost Outflow } \\
\text { time to } t\end{array}$ & $\begin{array}{c}\text { PV Inflow Benefits } \\
\text { time to } t\end{array}$ & \\
\hline 0 & 101.299 .360 & 0 & 1,00000000000000 & $101.299 .360,000$ & 0,0000 & $(101.299 .360,000)$ \\
\hline 1 & 31.495 .400 & 1.329 .060 & 0,87958483595743 & $27.702 .876,242$ & $1.169 .021,0221$ & $(26.533 .855,2203)$ \\
\hline 2 & 33.134 .800 & 25.851 .520 & 0,77366948364626 & 25.635.383,607 & $20.000 .532,1299$ & $(5.634 .851,4769)$ \\
\hline 3 & 39.306 .200 & 60.876 .160 & 0,68050794585826 & $26.748 .181,421$ & $41.426 .710,5933$ & $14.678 .529,1718$ \\
\hline 4 & 42.294 .200 & 94.232 .960 & 0,59856446992546 & $25.315 .805,404$ & $56.404 .501,7519$ & $31.088 .696,3480$ \\
\hline 5 & 46.042 .200 & 127.589 .760 & 0,52648823108933 & $24.240 .676,433$ & $67.174 .507,0475$ & $42.933 .830,6141$ \\
\hline 6 & 48.452 .700 & 160.946 .560 & 0,46309106437623 & $22.438 .012,415$ & $74.532 .913,7781$ & $52.094 .901,3632$ \\
\hline 7 & 48.500 .700 & 194.303 .360 & 0,40732787789272 & $19.755 .687,207$ & $79.145 .175,2962$ & $59.389 .488,0889$ \\
\hline $\begin{array}{l}\text { To } \\
\text { tal }\end{array}$ & 390.525 .560 & 665.129 .380 & & 273.135.983 & 339.853 .362 & 66.717.379 \\
\hline
\end{tabular}

Source: Primary Data Analysis (2020)

Net Present Value (NPV) is cash inflows minus cash outflows. NPV is one of the criteria in calculating investment to find out whether the business is feasible or not to be carried out. Based on the table above, the NPV obtained was IDR 66,717,379.00/Ha. If the NPV is $>0$, then it is feasible to cultivate red guava in Karanganyar District. This calculation was used as a consideration in cultivating red guava so that later it is known that this business will provide benefits and good prospects in the future.

IRR shows the project's ability to repay loan interest. If the IRR value is greater than or equal to the discount rate or MARR (Minimum Attractive Rate of Return), then the effort is worth the effort. The determination of IRR value was obtained by trial and error. In this calculation, positive NPV used $22 \%$ discount rate obtaining that the total value was IDR 4,983,939.06 and negative NPV used $23 \%$ discount rate, obtaining the total value of IDR $-671,964.65$. From the acquisition, the disc was put into the formula.

$$
\begin{aligned}
I R R & =0,22+\frac{4 \cdot 983 \cdot 939,06}{5 \cdot 610.903,71}(0,01) \\
& =0,2288 \text { or } 22,88 \% / \text { year }
\end{aligned}
$$


Based on these calculations, the IRR value obtained was $22.88 \%$. If the IRR value is greater than the prevailing interest rate, then the farming is feasible, and vice versa. So it can be seen that the IRR value $\geq 13 \%$ discount rate meaning that the business is feasible to run.

Net $B / C$ is the ratio between positive and negative NPV values. The positive NPV was IDR $200,185,446.00$, while the negative NPV was IDR $133,468,067.00$. The net $B / C$ ratio can be obtained using the following formula

$$
\begin{aligned}
\text { Net B/C Ratio } & =\frac{\sum_{\mathrm{t}=0}^{\mathrm{n}} \mathrm{NPV} \text { Positif }}{\sum_{\mathrm{t}=0}^{\mathrm{N} P V} \text { Negatif }} \\
& =\frac{200.185 .446}{133.468 .067} \\
& =1,50
\end{aligned}
$$

The Net $B / C$ value obtained from this red guava farming was 1.50 . This shows that each additional cost of IDR 1.00 will result in an additional benefit of IDR 1.50 for red guava farming in Karanganyar District. The resulting Net $\mathrm{B} / \mathrm{C}$ value is greater than 1. Based on these indicators, it can be concluded that red guava farming is feasible to be implemented.

The payback period is the time required to pay back (return) all costs that have been incurred in the investment of red guava farming. Payback period calculation is useful to know the ability of a business to return all investment costs. In the calculation, it can be seen that the time required for farmers to return all investment costs incurred is 6.04 years.

Indicators of business eligibility criteria are if the NPV is positive (NPV $>0$ ), then the IRR is greater than the prevailing bank interest rate (IRR>DR), and the Net $\mathrm{B} / \mathrm{C}$ ratio is greater than one (Net $B / C>1$ ) is feasible to run (Khotimah, 2014). So it can be concluded that red guava farming in Karanganyar District is feasible to be cultivated. This is explained by Tiara (2013), that investment feasibility analysis is used to determine production trends that will illustrate the relationship between production levels and plant age. This analysis produced a relationship between levels of production. Thus, the estimation of the amount of production per hectare per year at various plant ages can be obtained. This method assesses the benefits or investment feasibility of a project by paying attention to the time value of money so that the feasibility of a business can be determined.

Efforts that need to be done in order to increase farmers' income are the efficient use of production inputs, especially in the use of fertilizers. With the use of fertilizers and appropriate care in the cultivation of red guava, it will have an impact on the benefits obtained as expected.

\section{Red Guava Marketing Strategy Internal factors}

Internal factor analysis was used to analyze internal factors that affect the marketing of red guava in Karanganyar District. The results of the analysis of internal factors produced strengths and weaknesses which would be used as consideration in determining the red guava marketing strategy. In this analysis, there were 6 factors, those are product, price, distribution, promotion, finance, and management.

\section{External Factors}

External factor analysis was used to analyze external factors that affect the marketing of red guava in Karanganyar District. From this analysis, it can also be used to identify and evaluate things beyond control so that later the right strategy can be found to take advantage of opportunities and avoid threats. In this analysis, there were 5 factors, those are traders, consumers, competitors, government, environment, and socio-culture.

The Internal Factor Evaluation (IFE) Matrix is a strategy formulation tool to summarize and evaluate the main strengths and weaknesses in various functional areas in a business. The EFE matrix was used to summarize opportunities and threats in a business unit. This matrix was also used as a basis for identifying and evaluating relationships among areas such as marketing, finance, production, research and development, and the operation of company management information systems (Shojaie, 2014). The External Factor Evaluation (EFE) matrix is a strategic management tool that is often used to assess current business conditions. The EFE matrix is a great tool to visualize and prioritize the opportunities and threats encountered (Ommani, 2011).

The calculation results of IFE matrix can be seen in the table above, the score for strength is 2.143, while for weakness is 0.716 . It can be seen that red guava has strong strengths to minimize weakness. The difference between the strengths and weaknesses is 1.427. 
Table 4. IFE (Internal factor evaluation) matriks

\begin{tabular}{|c|c|c|c|c|}
\hline \multicolumn{2}{|r|}{ Internal factors } & \multirow{2}{*}{$\begin{array}{c}\text { Average } \\
\text { Weight }\end{array}$} & \multirow[t]{2}{*}{ Rating } & \multirow[t]{2}{*}{ Score } \\
\hline & $\begin{array}{l}\text { Strength } \\
\end{array}$ & & & \\
\hline 1 & Has thick flesh, red color and sweet taste & 0,129 & 4 & 0,516 \\
\hline 2 & Red guava production knows no season & 0,109 & 4 & 0,436 \\
\hline 3 & Prices are relatively affordable & 0,101 & 3 & 0,303 \\
\hline 4 & Have a lot of marketing networks & 0,121 & 4 & 0,484 \\
\hline \multirow[t]{3}{*}{5} & Own initial capital & 0,101 & 4 & 0,404 \\
\hline & Total & & & 2,143 \\
\hline & Weakness & & & \\
\hline 1 & $\begin{array}{l}\text { Farmers are less aware of making innovations from red } \\
\text { guava }\end{array}$ & 0,085 & 2 & 0,170 \\
\hline 2 & Farmers cannot determine the selling price & 0,085 & 2 & 0,170 \\
\hline 3 & Lack of incessant promotional activities & 0,072 & 1 & 0,072 \\
\hline 4 & Capital limitations & 0,090 & 1 & 0,090 \\
\hline \multirow[t]{3}{*}{5} & Poor management & 0,107 & 2 & 0,214 \\
\hline & Total & 1,000 & & 0,716 \\
\hline & Difference between strengths and weaknesses & & & 1,427 \\
\hline
\end{tabular}

Source: Primary Data Analysis (2020)

Table 5. EFE (External factor evaluation) matriks

\begin{tabular}{|c|c|c|c|c|}
\hline \multicolumn{2}{|r|}{ External Factors } & $\begin{array}{l}\text { Average } \\
\text { Weight }\end{array}$ & Rating & Score \\
\hline \multicolumn{5}{|c|}{ Opportunity } \\
\hline 1 & The sales network helps to expand the market & 0,136 & 4 & 0,544 \\
\hline 2 & Consumers come from various circles & 0,108 & 4 & 0,432 \\
\hline 3 & $\begin{array}{l}\text { Demand is increasing along with the increase of dengue } \\
\text { fever epidemic }\end{array}$ & 0,088 & 3 & 0,264 \\
\hline 4 & The quality of the fruit is different & 0,111 & 3 & 0,333 \\
\hline 5 & $\begin{array}{l}\text { The government's desire to promote guava in Karanganyar } \\
\text { District }\end{array}$ & 0,111 & 4 & 0,444 \\
\hline 6 & Natural conditions that support the cultivation of red guava & 0,117 & 4 & 0,468 \\
\hline \multicolumn{4}{|c|}{ Total } & 2,485 \\
\hline \multicolumn{5}{|c|}{$\begin{array}{ll}\text { Threat } \\
\end{array}$} \\
\hline 1 & Demand decreases when it coincides with other fruit seasons & 0,078 & 2 & 0,156 \\
\hline 2 & $\begin{array}{l}\text { The entry of the outer red guava fruit in the guava market in } \\
\text { Karanganyar District }\end{array}$ & 0,073 & 2 & 0,146 \\
\hline 3 & Lack of government assistance in managing guava & 0,077 & 2 & 0,155 \\
\hline \multirow[t]{3}{*}{4} & Pest and disease attacks & 0,100 & 2 & 0,200 \\
\hline & Total & 1,000 & & 0,656 \\
\hline & Difference between opportunity and threat & & & 1,829 \\
\hline
\end{tabular}

Source: Primary Data Analysis (2020)

The results of EFE matrix calculation in the table above obtained opportunities score of 2.485, while the threat is 0.656 . This indicates that red guava is strong in taking advantage of existing opportunities to minimize external threats. The difference between the opportunity and threat factors is 1,829 . This difference would be used later as a coordinate to determine the marketing position of red guava in Karanganyar District.

\section{Analysis of Company Position with the Grand Strategy Matrix}

Based on Figure 1, the score of the difference between strengths and weaknesses is 1.427 while the difference between opportunities and threats is 1.829. From this score, it can be seen that red guava in Karanganyar District is located in quadrant I. There needs to be a concentration on the current market (market penetration, market development) and current products (product development) is an appropriate strategy (Supratama, 2016). It is not wise for a company in quadrant I to move too far from the competitive advantage it has. This position indicates a strong and likely company. The internal strength of the company is used to seize opportunities that are outside (Amarala, 2019). 


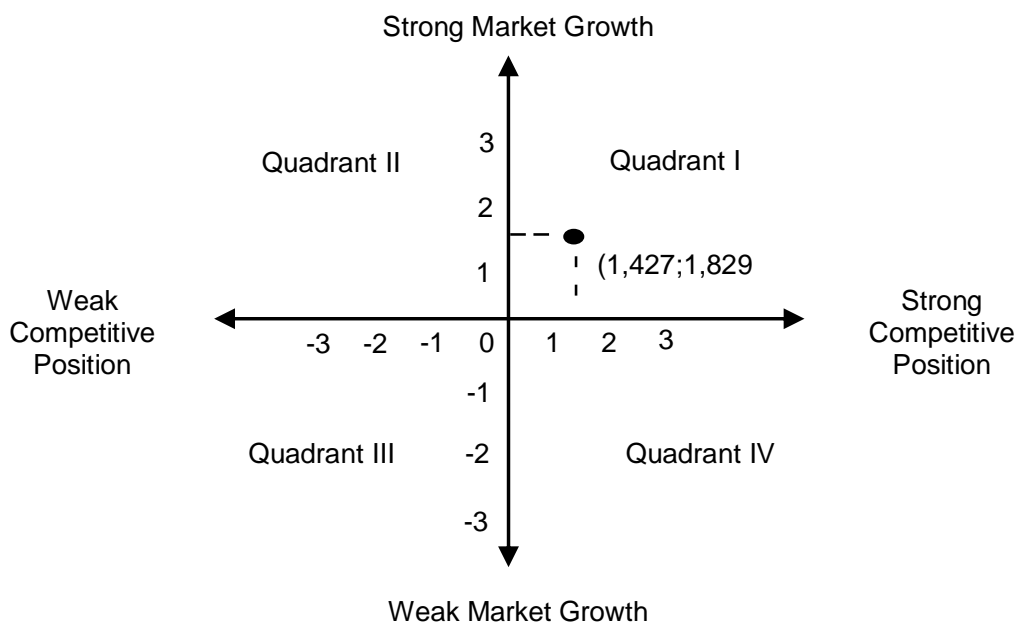

Figure 1. Results of the Grand Strategy Matrix Analysis

\section{Analysis of Alternative Marketing Strategies with the SWOT Matrix}

SWOT matrix is an important matching tool that helps farmers develop four types of strategies: SO (Strengths-Opportunities), WO (Weaknesses-Opportunities), ST (Strengths-Threats), and WT (Weaknesses-Threats). Based on the analysis of the company, it can be seen that the marketing of red guava in Karanganyar District is in quadrant I, so that in the SWOT matrix the strategy formulated was SO (Strengths-Opportunities) strategy. The final result of this analysis was the formulation of alternative strategies. Strategies were chosen by utilizing strengths and opportunities optimally and simultaneously controlling the weaknesses and threats encountered (Sopandi, 2017). There are 4 alternative strategies in marketing red guava in Karanganyar District, including:

1. Maintaining and improving the quality of red guava to maintain consumer confidence.

2. Maintaining affordable prices in order to win consumer trust.

3. Building cooperation between red guava farmers to meet market demand.

4. Promoting red guava to consumers.

\section{CONCLUSIONS AND SUGGESTION}

The feasibility of cultivating red guava based on the feasibility indicator means that this business is feasible to run. Alternative marketing strategies that can be applied by red guava farmers are to maintain and improve the quality of the fruit to maintain consumer confidence, maintain affordable prices in order to seize market position, cooperate between farmers to meet market demand, and promote to consumers. Suggestions that can be given are to maintain quality and price and the need for online and offline red guava promotion in Karanganyar District.

\section{REFERENCES}

Aluhariandu, V., Tariningsih, D, Lestari, F.K. (2016). Analisis Usahatani Jeruk Siam dan Faktor-Faktor Yang Mempengaruhi Penerimaan Petani (Studi Kasus di Desa Bayung Gede Kecamatan Kintamani Kabupaten Bangli). Jurnal Pertanian Berbasis Keseimbangan Ekosistem, 6(1), 77 86. Retrieved from https://jurnal.unmas.ac.id/index.php/agrimeta/article/view/509

Amarala, A. N. G. (2019). Strategi Pemasaran Produk Tempe Samodra Kelurahan Mojosongo, Kecamatan Jebres, Kota Surakarta. Universitas Sebelas Maret, Fakultas Pertanian.

BPS. (2019). Statistik Tanaman Buah-Buahan dan Sayuran Tahunan Indonesia 2018.

David. (2009). Manajemen Strategis Konsep-Konsep. Jakarta: Gramedia.

Fortunika, S. O., Istiyanti, E., \& Sriyadi. (2017). Kontribusi Sektor Pertanian Terhadap Perekonomian Kabupaten Banjarnegara. J of Agribusiness and Rural Development Research, 3(2), 119-127. Retrieved from https://journal.umy.ac.id/index.php/ag/article/view/3127

Kapantaw, G., Amisan, R.E, Laoh. (2017). Analisis Pendapatan Usahatani Kopi di Desa Purworejo Timur, Kecamatan Modayag, Kabupaten Boolang Mongondow Timur. Jurnal AgriSosioEkonomi Unsrat, 13(2), 229-236. Retrieved from https://ejournal.unsrat.ac.id/index.php/jisep/article/view/17014 
Khotimah, H. S. (2014). Analisis Kelayakan Finansial Usaha Budidaya Bambu. Jurnal IImu Kehutanan, 8(1), 14-24. Retrieved from https://jurnal.ugm.ac.id/jikfkt/article/view/8548

Kusumawati, R., Suwarto, Erlyna, W.R. (2013). Analisis Kelayakan Finansial Usahatani Kelapa Kopyor di Kecamatan Dukuh Seti Kabupaten Pati. Jurnal Agrista, 3(3), 354-365. Retrieved from https://www.neliti.com/id/publications/184049/analisis-kelayakan-finansial-usahatanikelapa-kopyor-di-kecamatan-dukuhseti-kabu

Muta'ali, L. (2019). Dinamika Peran Sektor Pertanian dalam Pengembangan Wilayah di Indonesia. Yogyakarta: UGM Press.

Ommani, A. (2011). Strengths, Weaknesses, Opportunities and Threats (SWOT) Analysis For Farming System Businesses Management : Case of Wheat Farmers of Shadervan District, Shoushtar Township, Iran. African Journal of Business Management, 5(22), 9448-9454. Retrieved from https://academicjournals.org/journal/AJBM/article-full-text-pdf/21F95E420498

Pasaribu, A. (2012). Perencanaan dan Evaluasi Proyek Agribisnis (Konsep dan Aplikasi). Yogyakarta: Andi Offset.

Shojaie, R., Taheri, S., \& Mighani, A. (2014). Strategic Planning For a Food Industry Equipment Manufacturing Factory, Using SWOT Analysis, QSPM, and MAUT models, University of Ershad Damavand, Iran. Asian Jurnal of Management Research, 1(1), 759-771. Retrieved from http://www.ipublishing.co.in/ajmrvol1no1/ElJMRS1059.pdf

Sopandi, E. (2017). Strategy of Business Development Bamboo Craft (A Study in Pasirjambu Village Pasirjambu District Bandung Regency. Jurnal AdBispreneur, 2(1), 1-17. Retrieved from http://jurnal.unpad.ac.id/adbispreneur/article/view/12876

Sugiyono. (2011). Metodelogi Penelitian Kuantitatif, Kualitatif dan R\&D. Bandung: Alfabeta.

Supratama, R. (2016). Strategi Bisnis Untuk Meningkatkan Daya Saing Township Jakarta Garden City. Jurnal Bisnis dan Manajemen, 52(11), 245-269. Retrieved from https://journal.untar.ac.id/index.php/bm/article/viewFile/731/620

Susanto, S., Inkorisa, D, Hermansyah, D. (2018). Pelilinan Efektif Memperpanjang Masa Simpan Buah Jambu Biji (Psidium guajava L.). Jurnal Hort Indonesia, 9(1), 19-26. Retrieved from http://journal.ipb.ac.id/index.php/jhi/article/view/22376

Tiara, M.D, Supardi, S., Sutrino, J. (2013). Analisis Investasi Konversi KomoditasKopi Ke Karet di PTPerkebunan Nusantara IX (Persero) KebunBatujamus/Kerjoarum Afdeling KaranggadunganKabupaten Karanganyar. Jurnal Agribusiness, 1(1) : 78-89.Retrieved from

Theresia, V., Anna, F., Netti, T. (2016). Pengambilan Keputusan Petani Terhadap Penggunaan Benih Bawang Merah Lokal dan Impor di Cirebon, Jawa Barat. Jurnal Agraris, 2(1), 50-60. Retrieved from https://journal.umy.ac.id/index.php/ag/article/view/1132 